\title{
Rodzina i jej obowiązki wobec najmłodszych na łamach prasy przełomu XIX i XX w.
}

Jednym z ważnych problemów społecznych II połowy XIX i początku XX w. była kwestia właściwej opieki nad dzieckiem i odpowiedzialności rodziny za jego wychowanie i edukację. Uwarunkowania ekonomiczne dużej części ówczesnego społeczeństwa polskiego generowały obszary biedy, a sytuacja dzieci - zdrowotna, wychowawcza oraz edukacyjna - była najgorsza. Problem ten dostrzegano szczególnie w miastach, gdyż, jak pisał Emilian Konopczyński:

[...] miasta jako siedliska przemysłu i handlu, nęcą ku sobie łatwością zarobku, stąd też napływ ludności i to najrozmaitszej jest do nich coraz większy. Tym świętszy jednak obowiązek spoczywa na sferach kierowniczych zwrócenie bacznej uwagi na wychowanie dzieci ludności mniej zamożnej, winny ułatwić one tym rodzicom, którzy pojmują świętość swych obowiązków ich należyte spełnienie, otoczyć zaś opieką, póki złe jeszcze wpływu swego nie rozpostarło, dzieci opuszczone lub osierocone ${ }^{1}$.

\section{Autor dodaje:}

[...] bo gdybyśmy nawet nie byli w stanie dokładnie policzyć dzieci pozostających bez opieki lub wychowawczego kierunku [...] to czyż same już liczne wypadki czynów przestępczych [...], nie świadczą, niestety, aż nadto wymownie o zdziczeniu obyczajów, braku jakiegokolwiek hamulca na złe popędy?².

Pomoc dzieciom z najuboższych warstw stała się priorytetowym zadaniem społeczeństwa. $Z$ jednej strony była to praca skoncentrowana na tworzeniu najbardziej potrzebującym odpowiednich warunków życia, również edukacji. Należało również wskazać rodzicom sposoby pokonywania wszelkich trudności. Z drugiej strony, trzeba było do pracy na rzecz najuboższych włączyć jak najszerszą reprezentację społeczeństwa. Stanowiło to nakaz wynikający nie

* Prof. zw. dr hab., Zakład Historii Edukacji, Instytut Pedagogiki, Wydział Nauk Historycznych i Pedagogicznych, Uniwersytet Wrocławski, ul. Dawida 1, 50-527 Wrocław.

${ }^{1}$ E. Konopczyński, W sprawie opieki nad ubogimi dziećmi, „Przegląd Pedagogiczny” 1897, nr 3, s. 37.

2 Tamże. 
tylko z dostrzeżonych problemów ekonomicznych, lecz w warunkach braku własnej państwowości ochrona tysięcy Polaków przed wynarodowieniem. Dla polskich warstw - liderów życia kulturalno-społecznego, objęcie opieką najuboższych stawało się obowiązkiem patriotycznym.

Liczni autorzy wypowiadali się niejednokrotnie na łamach prasy XIX i początków XX w. na temat funkcjonowania rodziny - niejednokrotnie nieporadnej, niewydolnej wychowawczo, powielającej model życia własnych rodziców i niedostrzegającej sposobów rozwiązywania trudnych problemów. Zagadnienia obowiązków rodziny omawiano z myślą o tych rodzicach, którzy mogli zabezpieczyć materialnie swoje dzieci, lecz nie przywiązywali wagi do spraw wychowania najmłodszych.

Szereg głosów w powyższych kwestiach drukowano w takich czasopismach, jak: „Przegląd Pedagogiczny”, „Kronika Rodzinna”, „Roczniki Gospodarstwa Krajowego”, „Przegląd Tygodniowy”, „Bluszcz”, „Zdrowie”, „Przegląd Wielkopolski”, „Ruch Chrześcijańsko-Społeczny”, „Szkoła” czy „Tygodnik llustrowany”. Autorzy tych artykułów, na przełomie XIX i XX w., najczęściej anonimowi bądź podpisani inicjałami, dowodzili powagi problemu rodzin „zagubionych” i mających trudności z realizacją swoich obowiązków. Wskazywano na drogi rozwiązywania problemów, niejednokrotnie zachęcając społeczeństwo do ofiarności na rzecz najuboższych. W propozycjach tych przede wszystkim przewijał się postulat powoływania odpowiednich zakładów, gdzie pod opieką pań-opiekunek dzieci „nie tyle nauki, ile wychowanie odbierały"3. Z kolei czytelnik z warstw tzw. średnich i wyższych dowiadywał się o istotnych sprawach związanych z wychowaniem dzieci.

Wielokrotnie podkreślano, że „wychowanie dziecka jest kształceniem człowieka tak dla własnego jego dobra i szczęścia, jak i dla obowiązków jego w społeczeństwie, którego jest członkiem"4. Najważniejsze w wychowaniu, według autora, jest kształtowanie charakteru, „charakter kształcić, charakter wyrabiać, to wychowania fundament najważniejszy; trudniejszym jest od nauczania, które ma gotowe już metody postępowania”. Wychowanie jest zadaniem rodziców, a „przy tych pierwszych jego początkach, które mają to znaczenie szczególne, bo dają istocie młodej nagięcie często wyroczne - dziełem matek, u których serca, powiedzieć można, wychowuje się dziecko”. Na łamach „Gazety Świątecznej” autorka artykułu pisze:

Wychowywać dzieci trzeba, wychowywać niemal od pierwszych chwil życia, aby, gdy podrosną i pójdą do szkoły [...], zło do nich łatwo nie przylegało, aby miały umysł rozwinięty do przyjęcia nauki, serce rozbudzone do miłowania tego, co dobre, a brzydzenie się fałszem i wszelkim złem. Wychowywać dzieci trzeba, żeby miały zdrowe ciało i zdrową duszę, żeby miały dobre nawyknienia, skromne obejście, żeby miały Boga w sercu, bo takie dzieci dłużej będą słuchały rad i wskazówek rodziców, w takich wyrobi się uczciwość i takich nauka prawdziwy pożytek przyniesie ${ }^{7}$.

${ }^{3}$ [A. hr. Z.], O zakładach dobroczynnych w kraju naszym, „Roczniki Gospodarstwa Krajowego” 1850, t. 17, s. 146.

${ }^{4}$ [M.I.], Wychowanie, „Szkoła” 1872, nr 32.

5 Tamże.

${ }^{6}$ Tamże.

7 P. R e s t o r f o w a, Nauka a wychowanie, „Gazeta Świąteczna” 1907, nr 1363, s. 4. 
Niejednokrotnie podkreślano że „rodzina to społeczeństwo w zmniejszeniu, jakie więc rodziny, takie społeczeństwo, taki naród”. Podobnie jak większość autorów publikacji twierdzono: „za głowę rodziny uważamy ojca, lecz główną przodowniczką jest matka-gospodyni. Wychowanie i wykształcenie dzieci spoczywa na barkach kobiety-matki"9.

Eliza Orzeszkowa, rzeczniczka rozwiązania kwestii najuboższych dzieci i pomocy dla najmłodszych, tak wypowiadała się w marcu 1876 r. w sali magistratu warszawskiego:

W wielkich ogniskach przemysłowych, tam gdzie tysiące kół w czarodziejsko zgodnym swym biegu grzmotem nieustającym napełniają powietrze; gdzie buchające z kominów dymy chmurą gęstą i czarną zasłaniają widok słońca i nieba; gdzie z rozcieranych materii ziemskich podnoszą się tumany krztuszącego pyłu; gdzie ciała chemiczne, rozkładowi poddane, zieją z siebie cuchnące gazy, a w proch niedojrzalny ulatniające się metale przenikają atmosferę nasionami chorób i śmierci - tam przez długich lat kilkadziesiąt widzieć można było nisko przy ziemi mrówiące się roje dzieci, od lat pięciu do czternastu wieku liczących ${ }^{10}$.

Trudna sytuacja materialna wielu rodzin sprawiała, że dzieci przebywały w ciasnych, nieogrzewanych komorach, najczęściej głodne. „Maleństwo szybko się oswaja z ulicą [...]. Ulica to jego dom, szkoła, widowisko, towarzystwo, odpoczynek, ucieczka - słowem cała kultura jaką odbiera. Rodzice jego nędzarze, materialnie, moralnie często i fizycznie"11. Nic dziwnego, że społeczeństwo „dojrzałe zanim się do sądu nad tą nędzą nieletnią zabierze, czuje we sumieniu własnym pewien bardzo słuszny niepokój nad rzeczywistym rozdziałem winy w tym wypadku, bo skoro to dziecko nie było przez nikogo wychowywane, przez nikogo nie strzeżone, nie ratowane, to jakże domagać się od niego przechowania skarbów moralnych, których mu nikt nie powierzył"12. Niedola dziecka wynikała z posiadania takich rodziców, których nikt nie wychowywał, „tak samo wzrośli na ulicy, w biedzie i złem, w pracy i zepsuciu”"13. W opinii autora, należało „tych rodziców wrócić dzieciom i przyrodzony nurt wychowania małego dziecka zawrócić w naturalne łożysko pierwotne - rodziny” ${ }^{14}$. Dodaje, że „im należy nieść ratunek duchowy, im przypomnieć, czego zapomnieli, ułatwić, co im za ciężkie”. W wypowiedziach licznych autorów często przewijał się wątek „podniesienia się na drodze moralnej ludności krajowej, wcielenie w lud wiejski idei moralnej"15. Rodzina włościańska, zajęta cały dzień pracą w gospodarstwie, nie mogła poświęcić uwagi najmłodszym dzieciom. „Dotąd włościanie urządzają się z dziećmi w ten sposób: biorąc je w czasie pogodnym z sobą w pole, lub powierzając opiece starszych

8 Z rozmyślań o rodzinie, „Przyjaciel Ludu” 1912, nr 1, s. 7

9 Tamże.

10 O niedolach dziecięcych. Odczyt p. Elizy Orzeszkowej, „Tygodnik llustrowany” 1876, nr 15, s. 234.

11 S z c z ę s n a, Niedola dziecka, „Bluszcz” 1897, nr 12, s. 90.

12 Tamże.

13 Tamże, s. 91.

14 Tamże.

15 Projekt etatu przychodu i wydatków Towarzystwa Rolniczego na r. 1860, „Roczniki Gospodarstwa Krajowego" 1860, t. 14-15, s. 423. 
pastuszków. Pierwszy środek jest niedogodnym, a drugi nie zawsze bezpiecznym"16. W tej sytuacji nie tylko sprawy opieki, ale i wychowania małego dziecka pozostawały poza rodziną.

Powyższe uwagi nawiązywały do sytuacji ludności wiejskiej. Na łamach kolejnego czasopisma można przeczytać: „nikt dziewcząt i matek wiejskich nie uczy o obowiązkach matki - czy ona dobrze wychowa dzieci, czy źle, to nikogo nie obchodzi” ${ }^{17}$. W kontekście życia miejskiego stwierdzano: „żadna warstwa społeczeństwa naszego nie jest tak pozbawioną możności zajęcia się, nie już wychowaniem, ale zwyczajnym dozorem swych dzieci, jak w ogóle uboższa klasa robotnicza miejska"18. Miasta generowały obszary biedy, pozostawiając dzieci bez pożywienia i schronienia.

Zostały bez kęsa chleba! Niewinne ofiary straszliwego przesilenia socjalnego $w$ Łodzi, długotrwałego lokautu. Potworna czekała je przyszłość. Dzieci robotników łódzkich z nędzy, być może, same odbierałyby sobie życie... Strach pomyśleć. Śmierć czyhała na nie bezlitośnie ${ }^{19}$.

W „Kurierze Warszawskim” w latach sześćdziesiątych XIX w. ukazywały się apele od ubogich i zdesperowanych matek:

Matka dwojga bliźniąt [...] poleca się względem łaskawych osób i zanosi prośbę, czy by kto jej dziatek nie chciał wziąć na wychowanie ${ }^{20}$.

Kto by z łaskawych państwa życzył sobie wziąć chłopczyka blisko dwuletniego, chodzącego i zaczynającego mówić, za swego, a to z powodu iż matka nie jest w stanie potrzeb jego zaspokoić, raczy się zgłosić pod nr 843 przy ul. Ogrodowej. Stróż miejscowy wskaże²1.

Na łamach czasopisma „Nowe Tory” zauważono: „gdzie tylko oczy zwrócimy, zauważymy rozkład i rozprężenie stosunków rodzinnych, które muszą wywrzeć smutny wpływ na rozwój potomstwa"22. Atmosfera rodziny, działania zgodne rodziców wobec dziecka wspomagają proces jego wychowania. „Jeżeli rodzina ma tworzyć jedną z podstaw społeczeństwa, powinna ona swym małoletnim członkom dać właściwy pokarm duchowy i pomóc im stać się ludźmi. I tylko wtedy, gdy życie rodzinne będzie ogniskiem, w którym się ześrodkują promienie światła i ciepła, odpowie ona swemu zadaniu"23. Podstawą stosunku rodziców do dzieci jest poczucie odpowiedzialności. „Rodzice żyją dla dziecka. Stąd to osobiste i codzienne zetknięcie obojga rodziców z obowiązkami wychowania, stąd zainteresowanie ogólne społeczeństwa kwestiami pedagogicznymi”24. Ideałem dobrej rodziny jest

16 O potrzebie u nas wiejskich ochron, „Przegląd Tygodniowy” 1875, nr 27, s. 313.

17 Żona ludowca z Suchodołu pod Krosnem. Głos kobiety wiejskiej, „Przyjaciel Ludu” 1904, nr 7, s. 4.

18 O potrzebie..., s. 313.

19 [Sgr.], Dzieci łódzkie, „Tygodnik llustrowany” 1907, nr 12, s. 252.

20 „Kurier Warszawski” 1864, nr 64, s. 391.

21 Tamże, nr 138, s. 838.

${ }^{22}$ M. He rtz b e rż a n k a, Znaczenie atmosfery rodzinnej w wychowaniu dzieci, „Nowe Tory” 1906, nr 7, s. 677.

23 Tamże, s. 682.

24 J. K r z y m u s k a, Rodzina współczesna, „Tygodnik Ilustrowany” 1897, nr 41, s. 804. 
„poświęcenie się rodziców dla dziecka, dla jego wychowania i przyszłości, podstawą miłość troskliwa i wyrozumiała; celem zapewnienie dziecku szczęścia takiego, jakiego ono samo będzie pragnąć" 25 . W artykułach prasowych niejednokrotnie zwracano uwagę, że „sfera tak zwanej inteligencji przedstawia wielką różnorodność warunków wpływających na rozwój umysłowy dziecka. W ogólności rodzice nasi inteligentni zajmują się troskliwie rozwojem fizycznym i umysłowym, częstokroć za nadto im chodzi o rozum i zdrowie fizyczne, a za mało o zdrowie moralne"26. Autor dostrzega „odmienne [...] warunki, w których wychowuje się dziecko na wsi od tych, w których żyje dziecko miejskie, a szczególnie wielkomiejskie. W sferze włościańskiej już w pierwszych latach życia pozostawiona jest dziecku nieograniczona swoboda, prawie bez współudziału starszych nabywa ono wiadomości o otaczającym świecie [...], rozwija się fizycznie i umysłowo. [...]. Nie przeczę, że swoboda taka dziecku przedstawia nie mało niebezpieczeństw fizycznych i moralnych"27.

Problemy z opieką i wychowaniem dzieci widziano w fakcie, że kobiety podjęły pracę zarobkową. Zaniedbania prowadziły do „moralnego zaniedbania, umysłowego zdziczenia takich bez opieki pozostawionych dzieci"28 i nieszczęśliwych wypadków, w których najmłodsi tracili zdrowie i życie. N. Jastrzębska przedstawiała ten problem w kontekście czasu, jaki mogłaby poświecić matka swoim dzieciom:

W czasach, kiedy kobieta nie wychodziła poza dom, dla zarobku, kwestia wychowania dzieci, czuwania nad nimi, rozwijania ich umysłu była tylko kwestią jej zdolności i dobrego rozłożenia zajęć domowych. Inna rzecz, czy większość matek stała na wysokości swego zadania [...]. Dziś jednak [...] cała ogromna rzesza kobiet [...] zmuszona została pracować na utrzymanie [...] i dzieci swych wychowywać już nie mogą 29 .

Autorka podejmuje kwestie nie tylko ubogiej części społeczeństwa. Odnosi się też do tych matek, którym „zdaje się często, że zabezpieczywszy materialne potrzeby dziecięcia, uczyniły już zadość obowiązkom matki, toż i powierzają dziecię swe sługom, kucharkom i osobom, których nadzór, których opieka stokroć więcej dziecku przynosi szkody, zepsucia, niż pożytku"30. Słusznie podkreślano że „rozwinięcie dziecka należy do matki, do rodziny i jak spostrzeganie przekonało, stanowi najważniejszą, stanowczą bo zasadniczą część wychowania. Działalność wychowawcza matki jest najszczytniejszą w życiu całym... jest jednak najtrudniejszą"31.

25 Tamże.

${ }^{26}$ W. O s t e r I o f f, O kształceniu umysłowym dzieci w okresie przedszkolnym, „Przegląd Pedagogiczny" 1890, nr 19, s. 341.

27 W. O s t e r I o f f, O kształceniu umysłowym dzieci w okresie przedszkolnym, „Przegląd Pedagogiczny" 1890, nr 18, s. 325.

28 I. M o s z c z e ń s k a, Opieka nad dziećmi, „Bluszcz” 1900, nr 14, s. 108.

${ }^{29}$ N. J a s t r z ę b s k a, Co robić z dziećmi?, „Bluszcz” 1910, nr 30, s. 321.

30 S. Stradom, Potrzeba zakładania ogródków dziecięcych, "Przegląd Pedagogiczny” 1884, s. 301.

31 Zakład gimnastyki, zabaw i rzemiosł dla dzieci i młodzieży w Warszawie, „Przegląd Tygodniowy" 1870, nr 17, s. 137. 
Działania liderów społecznych w zakresie pomocy rodzinie - materialnej, ale również w kwestii wychowania dzieci - zmierzały do powoływania odpowiednich placówek dla najmłodszych (ochrony, sierocińce i inne zakłady opiekuńcze). Miały tam się znaleźć dzieci całkowicie pozbawione opieki rodzicielskiej. Dla tych pozostających w rodzinie postulowano otwieranie ochronek - zakładów, funkcjonujących kilka godzin dziennie, oferujących przede wszystkim opiekę.

Z notatek prasowych, komunikatów, obszerniejszych artykułów i sprawozdań z działalności wybranych placówek można wnosić, że sprawa ochronek stała się dla społeczeństwa priorytetem. Wokół idei powoływania różnych instytucji dla małych dzieci skupiała się uwaga pojedynczych osób oraz stowarzyszeń i organizacji, niejednokrotnie tworzonych właśnie w tym celu. Intensywny ruch społeczny przyniósł konkretne rezultaty. Coraz większa liczba dzieci znajdowała opiekę i wychowanie, chociaż na podstawie czasopism można wnioskować, że zakres oddziaływania ochronek nie zadowalał ich organizatorów. Wskazywano miejsca, gdzie ruch ochroniarski dopiero się organizował. Pomimo krytycznych uwag w sprawie zakresu oddziaływania tego typu pomocy, dla rodziców pracujących było to znaczące wsparcie. Chodziło jednak o pomoc nie tylko pracującym rodzicom.

W tej rodzinnej ostoi, która u nas stokroć ważniejsze niż gdzie indziej ma znaczenie, często więcej od okoliczności zewnętrznych bruździ nam nieumiejętność rodziców lub niedostateczne przejęcie się ważnością zadań wychowawczych. Im silniejsze burze wstrząsają ścianami naszych domostw, tym większa pieczołowitość otaczać powinna okres, który przygotować ma nowe zastępy zdolne borykać się z przeciwnościami i mimo wszystko posuwać życie naprzód ${ }^{32}$.

Celem działalności ochronek było, „aby rodzicom biednym, zajętym całodzienną pracą nad zdobyciem środków istnienia przyjść z pomocą w wychowaniu dziatek, społeczeństwu przysporzyć jednostek zdrowych moralnie i fizycznie. Ochrony więc mają strzec dzieci od niebezpieczeństw, na jakie je może narażać brak opieki tak pod względem fizycznym, jak i moralnym: ale spełniając to tylko wypełniałyby one jedną i to mniejszą połowę swych obowiązków; druga wynikająca $z$ ich przeznaczenia ma na celu zainteresowanie rodziców, co jest daleko ważniejsze, a nawet $z$ powodu małego umysłowego a niekiedy i moralnego poziomu tychże rodziców całkowicie ciąży na ochronkach - jest to wychowanie"33.

Pierwsze ochronki zaczęły powstawać na ziemiach polskich w połowie XIX w. W Warszawie dzieło to podjął Stanisław Jachowicz wraz z grupą osób (w ramach działającego Towarzystwa Dobroczynności). Początkowo dla 12 sierot-chłopców stworzono przytułek, „ale szlachetne jego [Jachowicza - S.W.] serce cierpi nad tym, ponieważ wie on, że jest tylu bez opieki, bez żadnej tej pomocy, która broni od nędzy ducha i ciała, wkrótce też liczba ich wzrasta do 170"34. W kolejnych latach liczba placówek Towarzystwa Dobroczynności szybko rosła i w 1846 r. w stolicy guberni działało ich już 7 dla 436 dzieci. Niestety, kolejne kilkanaście lat

${ }^{32}$ M. L a sk ow i c zó w n a, Próba reformy wychowania przedszkolnego, „Nowe Tory” 1912, t. II, s. 70 .

${ }^{33}$ A. J u r g i e l e w i c z, Organizacja najpierwszego nauczania (w szczególnym zastosowaniu do ochron), „Przegląd Pedagogiczny” 1882, s. 149.

34 [M.J.], Stanisław Jachowicz, „Bluszcz” 1896, nr 18, s. 138. 
przyniosło zastój w pracy organizacyjnej Towarzystwa. Dopiero od 1858 r., kiedy jego prezesem został Tadeusz ks. Lubomirski, ponownie ożywił się ruch organizacji ochronek. Ponad trzydzieści lat kierowania przez niego Towarzystwem przyczyniło się do wzrostu liczby ochron z 7 do 33 (liczba dzieci - z 343 do ponad 5 tysięcy). W 1903 r. Towarzystwo miało pod opieką 38 zakładów dla około 7 tysięcy dzieci w wieku od 4 do 7 lat. Przykładem zakładu działającego pod zarządem Towarzystwa może być ochrona XXXIII, założona (1894 r.) „w ubogiej dzielnicy, tuż za rogatkami Jerozolimskimi, pierwsza w Warszawie, mająca własny budynek urządzony stosownie do wszelkich wymagań nowoczesnych" ${ }^{35}$. Cenne inicjatywy społeczne, zmierzające do objęcia opieką dzieci, koncentrowały się przede wszystkim na ochronkach. Powstawały też w Warszawie instytucje, które rozwijały się w kolejnych latach, jak np. „sale zajęć dla opuszczonych chłopców z okolicy placu św. Aleksandra"36, Pogotowie opiekuńcze dla dzieci (ul. Koszykowa 32), które wraz z tzw. Domem Opieki w Piasecznie tworzyło „[g]niazdo centralne Towarzystwa opieki nad dziećmi" ${ }^{37}$ czy założony w 1912 r. Dom Dziecięcy, który stanowił „syntezę nowszych poglądów i doświadczeń pedagogicznych i wcielenie higieny i psychologii wychowawczej, według programu, opracowanego przez S. Karpowicza"38. Zdecydowanie wolniej akcja zakładania ochronek postępowała na prowincji Królestwa Polskiego. Dlatego zachęcano na łamach czasopism właścicieli ziemskich do zakładania podobnych zakładów, dowodzą: „ochronę uważać należy za dzieło miłosierdzia, można odezwać się do serc odczuwających nędzę bliźniego, w nadziei, że ulitują się nad dolą nieszczęśliwych dzieci, podlegających okrutnym wypadkom i zajmą się ich zabezpieczeniem"39.

Na terenie Wielkiego Księstwa Poznańskiego pierwszą ochronkę dla małych dzieci założyło kasyno w Gostyniu (1845 r.). Wkrótce zaczęły powstawać kolejne, lecz „te tak dla W. Ks. Poznańskiego pożądane zakłady podupadły prawie zupełnie wśród szczęku broni i wstrząśnień rewolucyjnych w r. 1848"40. Po dwóch latach powrócono do akcji zakładania ochronek. W 1850 r. powstały w Pakosławiu (pow. bukowski), Porzeczu (pow. krobski), w Śremie i w Psarskiem (pow. śremski). W Poznaniu w swoim domu pp. Tytusostwo Działyńscy założyli ochronkę dla 200 dzieci ${ }^{41}$. W Wielkopolsce szczególny nacisk kładziono na zakładanie ochronek wiejskich, których początki wiąże się z osobą Edmunda Bojanowskiego.

Bez przeszkód rozwijały się ochronki na terenie Galicji. W drugiej połowie XIX w. znaczący wkład w organizację placówek, obok osób prywatnych i władz krajowych, miał Kościół katolicki. Podobnie jak na pozostałych ziemiach polskich, w Galicji podkreślano rolę ochronek, które przynajmniej w pewnym zakresie zastępowały wychowanie rodzicielskie i domowe.

${ }^{35}$ ks. H. S k i m b o r o w i c z, Ochrona XXXIII, „Tygodnik Ilustrowany” 1898, nr 22, s. 488.

36 Ochronka ks. Ordona w Mławie, „Tygodnik llustrowany” 1899, nr 2, s. 83.

${ }^{37}$ A. K r y s i ń s k i, Pogotowie opiekuńcze dla dzieci, „Tygodnik llustrowany” 1912, nr 43, s. 895.

${ }^{38}$ A. S o b o l e w s k a, Dom Dziecięcy, "Wychowanie w domu” 1912, nr 4, s. 287; "Nowe Tory” 1912, t. I, s. 447.

${ }^{39}$ [A.Gr.], Ochrony dla wiejskich dzieci, „Kronika Rodzinna” 1893, nr 9, s. 257.

40 S. K a rw o w s k i, Pierwsze w W. Ks. Poznańskim ochronki, „Przegląd Wielkopolski” 1914, nr 6, s. 141.

41 Tamże, s. 143. 
Prezentując $\mathrm{w}$ wielkim skrócie problem ochronek, należy dodać, że wiele z nich włączało nowoczesne metody pracy z najmłodszymi. Było to zasługą przede wszystkim opiekunek, które poprzez samokształcenie zdobywały wiedzę na temat nowych nurtów w pedagogice, w tym metody W. F. Froebla. W związku z tym szereg ochronek łączyło zadania opiekuńcze z wychowaniem i rozwijaniem umysłowym dziecka, przede wszystkim poprzez zabawy, gry i gimnastykę, naukę piosenek, opowiadanie oraz rysowanie.

Wśród zakładów przeznaczonych dla małych dzieci w drugiej połowie XIX w. zaczęły powstawać ogródki dziecięce - zakłady freblowskie, których ideę łączy się z koncepcją pedagogiczną W. F Froebla i początkami wychowania przedszkolnego.

Redaktor naczelny „Przeglądu Tygodniowego”, Adam Wiślicki, przyczynił się do zorganizowania oddziału freblowskiego przy istniejącej w Warszawie IX Ochronce im. ks. Baudonina (1867). Pomysł ten traktowano jako eksperyment pedagogiczny, ale równocześnie dla idei ogródka udało się zjednać grono nauczycielek warszawskich, m.in. Wandę Skłodowską i Teresę Mleczko. Po roku oddział freblowski został zlikwidowany ze względu na brak środków finansowych. W 1869 r. wymienione nauczycielki otworzyły placówkę dla małych dzieci (ul. Królewska) pod nazwą Zakład gimnastyki, zabaw i rzemiosł dla dzieci i młodzieży, „zbliżony zupełnie organizacją do ogródków freblowskich”42. Niestety i ta placówka została zamknięta po dwóch latach ze względu na problemy finansowe.

Ostatecznie ogródki dziecięce wpisały się w krajobraz edukacyjny Królestwa Polskiego od 1874 r., kiedy T. Mleczko reaktywowała w Warszawie przy ul. Wiejskiej 16 swój ogródek, który po śmierci założycielki podzielił los wcześniejszych tego typu inicjatyw i został zlikwidowany w $1885 \mathrm{r}$.

Na łamach prasy z uznaniem pisano o freblowskiej metodzie pracy z najmłodszymi, lecz jednocześnie wyrażano zdziwienie, że „ta wyborna metoda tak mało u nas znalazła dotychczas uznania i poparcia w sferach inteligentnych; wszak w całej Warszawie dwa zaledwie znajdują się zakłady tego rodzaju: p. Mleczkowej i panny Friedmann"43. Na temat zakładu Mleczkowej czytamy:

[...] o ile wiemy, z początku budził wielkie wśród publiczności zajęcie, powstał takiż sam zakład we Włocławku, a co najważniejsze, że tę metodę zaczęto i w domowym wychowaniu stosować. Na czemże się jednak te wszystkie usiłowania skończyły, co do rozpowszechniania owej metody. Oto jak każda nowość, z początku zrobiła wiele hałasu; dziś zaś jedyny jej ślad pozostał w zakładzie pani Mleczowej, ale ten obecnie musiano zamienić na szkołę początkową, gdyż rodzicom zdawało się, że dzieci tylko zabawkami zajęte na próżno czas marnują ${ }^{44}$.

Ponownie, po dwóch latach (1887), ogródek założyła Maria Weryho, niestrudzona propagatorka nowych form pracy z małym dzieckiem. Przy swojej freblówce powołała kursy dla freblanek, których absolwentki włączały się w coraz szerszy nurt upowszechniania ogródków dziecięcych i wkrótce przedszkoli. Na-

${ }^{42}$ Zakład gimnastyki, zabaw i rzemiosł dla dzieci i młodzieży w Warszawie, „Przegląd Tygodniowy" 1870 , nr 17, s. 137.

${ }^{43} \mathrm{~S}$. Stra do m, Potrzeba zakładania ogródków freblowskich, „Przegląd Pedagogiczny” 1883, s. 302.

${ }^{44}$ [R.P.], Z dziedziny pedagogiki, „Kłosy” 1878, nr 657, s. 70. 
leży podkreślić, że były to nieliczne inicjatywy - przede wszystkim w Warszawie, przeznaczone dla zamożnych dzieci. Małe grupy najmłodszych, świetnie wyposażone pomieszczenia, przemyślany dobór zabawek i dobrze przygotowana kadra wychowawczyń, miały przecierać drogi dla podobnych zakładów obejmujących większą liczbę dzieci, również z najbiedniejszych domów.

Inaczej potoczyły się losy freblówek w Galicji. Władze austriackie i Rada Szkolna Krajowa (RSK) uznały ogródki dziecięce za ważną formę opieki nad małym dzieckiem i wychowania go. Fakt ten uwzględniono w ustawie szkolnej z 1868 r., wprowadzając wymóg organizowania przy szkołach ludowych „zakładów dla pielęgnowania, wychowania i nauczania dzieci jeszcze nie obowiązanych do uczęszczania do szkoły"45. W reskrypcie ministerialnym z 22 czerwca 1872 r. dokładnie określono zadania i cele, stawiane przed freblówką w odróżnieniu od istniejących w Galicji instytucji opieki nad najmłodszymi, jakimi były ochronki. Jednak reskrypt RSK z 8 czerwca 1884 r. zatarł jasno ustaloną granicę między ogródkami freblowskimi a ochroną. Władze szkolne nakłaniały wychowawczynie, aby zasady wychowawcze stosowane w ogródkach przenieść do ochron, z kolei ogródki miały przejmować funkcje opiekuńcze ochron. Równocześnie minister oświaty wystąpił „przeciwko szkółkom freblowskim, do których u nas należą również ochronki, zakazując w nich uczyć czytać, pisać, rachować, słowem tego, co wchodzi w atrybucje szkoły elementarnej. Jest to reskrypt przeciw naszym ochronkom wymierzony, aby dzieci nie zaznały nauki pisania i czytania polskiego, gdyż szkoła skoro o to nie dba, to też i zakłady opiekujące się dziećmi przed rokiem szkolnym, tym się zajmować nie powinny"46. Podobnie jak w Królestwie Polskim, tak i w Galicji z freblówek korzystały dzieci z zamożnych rodzin, które wnosiły opłaty, dlatego też „ogródki, jako instytucje płatne mają fundusz na zaopatrzenie się we wszystkie potrzebne i wymagane przez metodę Froebla przybory"47. Pomimo poparcia idei freblizmu przez koła pedagogiczne Galicji, w społeczeństwie miała dość nikły oddźwięk.

W zaborze pruskim początkowo okólnik z 11 lutego 1852 r. ministra Raumera zakazywał prowadzenia ogródków freblowskich. Nim minęło 12 lat, władze pruskie nie tylko przestały zgłaszać zastrzeżenia do systemu Froebla, lecz także zaczęły go wspierać. Po 1873 r. stawiano dodatkowe wymagania organizatorom polskich freblówek i ochronek, m.in. polecano nauczać dzieci języka niemieckiego. Pomimo wielu utrudnień, w 1905 r. istniało w Poznaniu 10 polskich freblówek.

Do inicjatyw zarówno wspomagających rozwój dziecka, jak i niosących pomoc rodzinie w wychowaniu najmłodszych można zaliczyć ogrody dziecięce. Początki sięgają roku 1899, gdy na wniosek T. Halickiego wydział wychowawczy Towarzystwa Higienicznego postanowił zająć się urządzeniem zabaw dla dzieci w Warszawie, tworząc w krótkim czasie trzy ogrody: najdawniejszy w Agrykoli, następny - plac oddzielony w Ogrodzie Saskim, w pobliżu ul. Żabiej oraz duży plac w Agrykoli dolnej. Rok później zorganizowano pięć dodatkowych miejsc do

45 J. B u z e k, Studia z zakresu administracji wychowania publicznego, cz. I: Szkolnictwo ludowe, Lwów 1904, s. 41.

46 „Szkoła” 1884, nr 27, s. 188.

47 J. A. A l e k s o t a, Ochronki galicyjskie i ogródki freblowskie, „Bluszcz” 1897, nr 16, s. 125. 
zabaw. Jednak pierwszym, stałym ogniskiem wychowania fizycznego w Warszawie były Ogrody im. W. E. Rau'a ${ }^{48}$. Przykład stolicy zaktywizował w tym kierunku środowiska wielu miast. W 1904 r. ogrody istniały w Wilnie (urządzone staraniem Towarzystwa Opieki nad Ubogimi Dziećmi), w Płocku (z inicjatywy doktorowej Chmielińskiej) i w Kaliszu (powołany przez kaliski oddział Towarzystwa Higienicznego). W Galicji, oprócz istniejącego parku dr. Jordana w Krakowie, podobny ogród utworzono we Lwowie. Zakładanie ogrodów miało przede wszystkim przeciwdziałać złym warunkom życia miejskiego, które fatalnie wpływały na rozwój dziecka. Ponadto, jak stwierdzano, „rodzice ubodzy i nieoświeceni nie mogą i nie umieją zająć się dziećmi, puszczają je więc samopas, rzucając na pastwę złych wpływów ulicy, przez co do skarłowacenia fizycznego dołącza się wczesne zepsucie moralne. Rodzice zamożniejsi i mający pretensje do inteligencji albo sądzą, że wszystkie swe obowiązki spełnili, gdy oddali dziecko do szkoły i napędzają je ciągle do książki, zaniedbując zupełnie wychowanie fizyczne, lub też, mniej dbali o uczoność, niż o szyk światowy, nie znają innej zabawy dla swych dzieci, prócz balonów dziecinnych, będących pierwszą szkołą próżności i kokieterii" ${ }^{4}$. Szycówna dodaje: „otóż ogrody dziecięce są protestem zdrowej myśli pedagogicznej przeciwko niezdrowym warunkom życia i wychowania" ${ }^{50}$.

Rodzina przeżywała poważne trudności w czasie I wojny światowej. Opieka nad najmłodszymi, rozbudowywana na początku XX w., załamała się.

Podczas wojny światowej bezsprzecznie najbardziej ucierpiało nasze najmłodsze pokolenie, a to pod względem fizycznym i moralnym. Skąpe i liche odżywianie dzieci spowodowało małą odporność, to też choroby różnego rodzaju szerzyły się w świecie dziecięcym w sposób zastraszający, a śmierć miała obfite żniwo z powodu braku opieki, lekarstw potrzebnych, a w niektórych miejscowościach nawet lekarzy. Jeszcze niebezpieczniejszym może nieprzyjacielem naszej młodzieży - to zepsucie moralne ${ }^{51}$.

Okres wojenny nie sprzyjał tworzeniu i rozwijaniu zakładów oferujących opiekę częściową. Z jednej strony skupiono się na doraźnych działaniach, przede wszystkim w zakresie pomocy materialnej. Dostrzegano jednak problemy dzieci zagubionych i osieroconych - ten fakt m.in. był bezpośrednią przyczyną utworzenia w sierpniu 1915 r. zakładu opiekuńczego we Lwowie.

Pierwotnym celem ochronki było dać opiekę i przytułek - choćby czasowo - dzieciom legionistów polskich w ciężkich dniach wojny; następnie zaś po uspokojeniu zamieszek wojennych, w miarę nowego kształtowania się stosunków społecznych, zadaniem tej instytucji stała się systematyczna i umiejętnie stosowana działalność wychowawcza, który by zapewniła sierotom powierzonym zakładowi odpowiednie warunki rozwoju i wykształcenia zawodowego oraz uczyniła z nich z czasem dzielnych pracowników i pożytecznych obywateli Państwa Polskiego ${ }^{52}$.

${ }^{48}$ S. K a r p - R o t t e r m u n d, Ogrody imienia W. E. Rau'a, „Zdrowie” 1910, z. 8, s. 578.

${ }^{49}$ A. S z y c ó w n a, Ogrody dziecięce imienia Rau'a, „Zdrowie” 1904, z. 1, s. 5.

50 Tamże, s. 6.

${ }^{51}$ Kilka uwag o opiece nad dziećmi i młodzieżą, „Poseł Związku Śląskich Katolików” 1919, z. 44 , s. 16.

52 Sprawozdanie z działalności ochronki i internatu im. J. Piłsudskiego wre Lwowie za lata 1928/29, 1929/30 i 1930/31, Lwów 1931, s. 3. 
Sytuacja dzieci nie zmieniła się natychmiast po zakończeniu działań wojennych. Kolejne konflikty zbrojne lat 1918-1921 wymagały intensywniejszych zabiegów opiekuńczych i pomocowych na rzecz rodziny i najmłodszych.

Normująca się sytuacja polityczna i społeczna w II Rzeczpospolitej nie oznaczała, że ostatecznie został rozwiązany problem opieki nad dziećmi. Powróciły znane już z przeszłości kwestie. „Jednym z najbardziej palących zagadnień doby obecnej jest zagadnienie, jak pogodzić dążenie kobiet współczesnych do pracy zarobkowej, do stanowisk samodzielnych z obowiązkami matki" ${ }^{3}$. Podkreślano wagę tej kwestii, gdyż „,wychowanie dziecka wymaga obecnie większej niż kiedykolwiek pracy, bo wzmożonej znacznie czujności i jeszcze głębszego zrozumienia ważności zadania, wskutek ogólnego stanu zwątlenia powojennych młodych pokoleń, zarówno pod względem fizycznym, jak i, niestety, moralnym" ${ }^{4}$.

W nowych warunkach politycznych i społecznych działania na rzecz rodziny i dziecka podjęły władze państwowe, samorządowe, towarzystwa i stowarzyszenia oraz kościół katolicki. Najważniejsze były próby zsynchronizowania pracy (co nie zawsze się udawało) również na płaszczyźnie legislacyjnej. Odbiorców pomocy było wielu. Konsekwentnie skoncentruję się na tych zakładach opiekuńczo-wychowawczych i edukacyjnych, które przed I wojną światową występowały pod nazwami: ochronka, ogródek dziecięcy i - sporadycznie - przedszkole.

Dyskusja podjęta na łamach „Przyjaciela Szkoły” ${ }^{5}$, której celem było wskazanie rozdzielność ochronki i przedszkola, nie do końca sprawdziła się w praktyce. Kwestie związane $z$ wychowaniem małego dziecka w dalszym ciągu stanowiły główny problem dla wielu autorów, publikujących na łamach ówczesnych czasopism. „Większość dzieci nie znajduje w rodzinie swojej warunków wychowawczych - pisała A. Kozłowska - Nie jest dobrą wychowawczynią matka ciemna, walka z niedostatkiem i niejednokrotnie złym pożyciem małżeńskim zdenerwowana do ostatniego stopnia, przy tym zupełnie nieprzygotowana do pracy wychowawczej. Matka, która wychowuje nieustannym narzekaniem na dzieci i dyscyplinarnymi zabiegami, jedynie obrzydzi dzieciom swoim pierwsze lata życia"56. W dalszej części artykułu autorka kontynuuje:

Nie jest też wychowawczynią służąca, nie mająca pojęcia o pedagogii, niechętnie zastępująca matkę z inteligencji pracującej, która, zmuszona koniecznością, z bólem serca zgodziła się wyjść $z$ domu, aby na równi z mężem pracować na utrzymanie rodziny. Pozostają więc matki dobrze sytuowane. Drobna jest ich liczba, a jeszcze połowa z nich, zajęta życiem towarzyskim, dancingami i strojem, mało poświęca się wychowaniu swoich dzieci, powierzając je osobom obcym ${ }^{57}$.

Stąd wielu pedagogów i praktyków wskazywało, że najlepszym miejscem służącym wychowaniu dziecka jest przedszkole, które winno być dostępne również dla najuboższych. Właściwie realizowany program wychowawczy i dydaktyczny

53 Z. G r z y m a ło w s k a, Wychowuj dziecko sama, „Rodzina Polska” 1928, nr 12, s. 379.

54 Tamże.

55 Ochronka - przedszkole, „Przyjaciel Szkoły” 1925, nr 2, s. 50-56.

56 A. K o z ł o w s k a, Co wychowanie przedszkolne może dać dziecku, „Przyjaciel Szkoły” 1927, nr 14, s. 621.

57 Tamże, s. 621-622. 
miał być znaczącą pomocą dla rodziców - reprezentantów różnych warstw. Jednak proces zakładania przedszkoli, zapewnienia właściwie przygotowanej kadry i uświadomienia rodzicom wagi realizowanych zadań dydaktyczno-wychowawczych trwał przez cały okres istnienia II Rzeczpospolitej.

W drugiej połowie XIX i na początku XX w. podkreślano na łamach prasy rolę rodziny w wychowaniu dzieci. Zwracano uwagę szczególnie na tych, którzy nie mogli stworzyć właściwych warunków bytowych, a tym samym i edukacyjnych swoim dzieciom. Dostrzegano też, że zabezpieczenie materialne dziecka w rodzinach nie zawsze tworzy warunki właściwego wychowania. Podkreślano, że niejednokrotnie zapracowane matki nie są w stanie zapewnić swoim dzieciom prawidłowego rozwoju fizycznego i psychicznego. Dlatego też poszukiwano instytucji, które mogłyby, chociaż w minimalnym zakresie, wypełnić zadania rodziny. Tymi instytucjami były m.in. ochronki, ogródki dziecięce i przedszkola.

W prasie przypominano, że „rodzina, w szerokim tego słowa pojęciu, to siła. To siła, która dopomaga do przeniesienia nieszczęścia, to siła, do której młodzi mogą udać się zawsze po opiekę i radę. Rozwinięta solidarność rodzinna prowadzi do obudzenia solidarności sąsiedzkiej, ta do regionalnej, ta wreszcie do solidarności narodowej" ${ }^{\prime \prime}$.

${ }^{58}$ N. B o g u s z o w a, Kult rodziny w wychowaniu, „Ziemianka Polska” 1929, nr 3, s. 7. 